\title{
Alkali Treatment of Commercial Silicoaluminophosphate Molecular Sieves (SAP0-34) Enhances the Water Adsorption and Desorption Properties
}

\author{
Masahiro Katohi $^{*}$, Kota Horiuchi², Ayaka Satoh'², Kota Aoyagi², Shigeru Sugiyama1 \\ ${ }^{1}$ Department of Applied Chemistry, Graduate School of Technology, Industrial and Social Sciences, Tokushima University, \\ Tokushima, Japan \\ ${ }^{2}$ Department of Chemical Science and Technology, Tokushima University, Tokushima, Japan \\ Email: *katoh@tokushima-u.ac.jp
}

How to cite this paper: Katoh, M., Horiuchi, K., Satoh, A., Aoyagi, K. and Sugiyama, S. (2019) Alkali Treatment of Commercial Silicoaluminophosphate Molecular Sieves (SAPO-34) Enhances the Water Adsorption and Desorption Properties. Journal of Encapsulation and Adsorption Sciences, 9, 149-158.

https://doi.org/10.4236/jeas.2019.94008

Received: October 5, 2019

Accepted: December 3, 2019

Published: December 6, 2019

Copyright $\odot 2019$ by author(s) and Scientific Research Publishing Inc. This work is licensed under the Creative Commons Attribution International License (CC BY 4.0).

http://creativecommons.org/licenses/by/4.0/

\section{(c) (i) Open Access}

\begin{abstract}
Commercial silicoaluminophosphate molecular sieves (SAPO-34) received alkali treatment with either $\mathrm{NaOH}(0.2,0.01,0.005$, or $0.001 \mathrm{M})$ or $\mathrm{NH}_{4} \mathrm{OH}$ $(0.005 \mathrm{M})$. Treatment with $\mathrm{NaOH}(0.005 \mathrm{M})$ increased the water adsorption initial rate of SAPO- 34 by 1.4 -fold. The alkali treatment introduced $\mathrm{Na}^{+}$adsorption sites into the SAPO-34. The desorption ratio (adsorption at $30^{\circ} \mathrm{C}$ and desorption at $100^{\circ} \mathrm{C}$ ) was $88.2 \%$ higher than the original rate $(84.3 \%)$. On the other hand, after alkali treatment of SAPO-34 using $\mathrm{NH}_{4} \mathrm{OH}(0.005 \mathrm{M})$, calcination resulted in the highest desorption ratio at $91.3 \%$. When combined with calcination, alkali treatment with $\mathrm{NH}_{4} \mathrm{OH}$ introduced $\mathrm{H}^{+}$adsorption sites into SAPO-34, $\mathrm{H}^{+}$adsorption sites feature low levels of interaction with water, which enhanced the desorption ratio, but decreased the initial adsorption rate. These results indicate that treating commercial SAPO-34 with 0.005 $\mathrm{M} \mathrm{NaOH}$ enhances both the adsorption and desorption behaviors.
\end{abstract}

\section{Keywords}

Alkali Treatment, Silicoaluminophosphate Molecular Sieves, Water, Adsorption, Desorption

\section{Introduction}

In 1984, a novel class of oxide molecular sieves with a crystalline microporous framework, silicoaluminophosphates, was synthesized [1] [2]. These new materials possess properties of both zeolites and aluminophosphetes, which makes 
them unique in many ways. The present study was focused on commercial silicoaluminophosphate molecular sieves (SAPO-34 (AQSOA-Z02,)) that were supplied by the Mitsubishi Chemical Corp. The water adsorption isotherm of AQSOA-Z02 revealed interesting behaviors [3]. The adsorbed amount of water increased rapidly at $10 \%$ relative humidity and the adsorbed amount of water corresponded to the amount that would saturate a Y type zeolite. The results of alkali treatment for both $\mathrm{NaY}$ zeolites [4] and ZSM-5 type zeolites [5] were reported previously. Water diffusivity was enhanced for $\mathrm{NaY}$ zeolites via alkali treatment with $1 \mathrm{M}$ of a $\mathrm{NaOH}$ solution. This concentration was too high, however, for the alkali treatment of ZSM-5 zeolites, and the concentration was decreased to an optimum of $0.2 \mathrm{M}$.

In the present study, SAPO-34 was treated with either $\mathrm{NaOH}(0.2,0.01,0.005$, or $0.001 \mathrm{M})$ [4] [5] or $\mathrm{NH}_{4} \mathrm{OH}(0.005 \mathrm{M})$ with the goal of achieving a higher rate of water diffusivity. The modified SAPO-34 was characterized by XRD, SEM, XRF, IR, and nitrogen adsorption. The amount of water adsorbed onto zeolites under the recycled temperature conditions was estimated using the IR method [6]. The IR spectra of water adsorbed onto zeolites were measured under differential temperatures at a constant pressure. The water adsorption behavior was estimated by measuring the change of pressure under a constant volume [4] [5] [7].

\section{Experimental Methods}

All experiments were performed at Tokushima University from April, 2015 through September, 2019.

\subsection{Materials}

The SAPO-34 (AQSOA-Z02) used in this study was supplied by the Mitsubishi Chemical Corp. The Alkali treatment of AQSOA-Z02 was performed within an aqueous solution of either $\mathrm{NaOH}(0.2,0.01,0.005$, or $0.001 \mathrm{M})$ or $\mathrm{NH}_{4} \mathrm{OH}(0.005$ $\mathrm{M})$. Then, $1.0 \mathrm{~g}$ of AQSOA-Z02 was placed into a $100 \mathrm{~mL}$ of each aqueous solution and was kept at $95^{\circ} \mathrm{C}$ for $1 \mathrm{~h}$. After a period of $1 \mathrm{~h}$, the slurry was filtered using a filter media made of glass fiber with $0.3 \mu \mathrm{m}$ pores. The filtered cake was dried overnight at $100^{\circ} \mathrm{C}$ in an air oven. After drying, the cake was crushed into powder, and the powder was rinsed with hot distilled water at $80^{\circ} \mathrm{C}$ for $2 \mathrm{~h}$. After rinsing, the powder was filtered and dried to obtain either $\mathrm{Z} 02-\mathrm{NaOH}(\mathrm{X} \mathrm{M})$ (X denoted the concentration of $\mathrm{NaOH}$ aqueous solution) or $\mathrm{Z} 02-\mathrm{NH}_{4} \mathrm{OH}(0.005$ $\mathrm{M})$. As a reference, $\mathrm{Z} 02-\mathrm{NH}_{4} \mathrm{OH}-\mathrm{C}$ was obtained by calcination of $\mathrm{Z} 02-\mathrm{NH}_{4} \mathrm{OH}$ $(0.005 \mathrm{M})$ at $470^{\circ} \mathrm{C}$ for $4 \mathrm{~h}$.

The crystalline structure of the samples was checked via X-ray diffraction microscopy (RINT2500-VHE; RIGAKU Corp.). SEM images were obtained using a JEOL JSM-6390HV microscope. The $\mathrm{P} / \mathrm{Al}, \mathrm{Si} / \mathrm{Al}$ and $\mathrm{Mg} / \mathrm{Al}$ ratios and $\mathrm{Na}$ content were measured by X-ray fluorescence analysis (JSM-3020M; JEOL Ltd.) The pore properties were determined by nitrogen adsorption at $-196^{\circ} \mathrm{C}$ (BELSORP-max; 
MicrotracBEL Corp.). The micropore and mesopore volumes were evaluated using the MP and $\mathrm{BJH}$ method, respectively.

\subsection{Measurement of the Thermal Behavior of Water Adsorbed Onto Samples}

The infrared (IR) spectra of the water-alkali treated SAPO-34 adsorption systems were obtained using the IR cell reports from other papers [4]-[10]. A sample disc that was $13 \mathrm{~mm}$ in diameter, approximately $8.5 \mathrm{mg}$ in weight, and approximately $60 \mu \mathrm{m}$ in thickness was pretreated in the cell at $350^{\circ} \mathrm{C}$ and $4.0 \times 10^{-4}$ Torr for $2 \mathrm{~h}$. The spectra were recorded on a FTX3000MX Bio-Rad Laboratories, Inc. spectrometer with a mercury-cadmium-telluride (MCT) detector at a resolution of $4 \mathrm{~cm}^{-1}$. The spectra were recorded by increasing the temperature from $30^{\circ} \mathrm{C}$ to $200^{\circ} \mathrm{C}$ and under water pressure of 10 Torr. The IR integrated intensity of the peak around $1650 \mathrm{~cm}^{-1}$, which was assigned to the bending vibration of adsorbed water, was normalized by the weight and diameter of the sample disc. The IR normalized intensity was equivalent to the amount of adsorbed water at a given temperature.

\subsection{Measurement of the Water Adsorption and Desorption Behavior of Several Samples}

Water adsorption was measured using a volumetric adsorption apparatus assembled in our laboratory [4] [5] [7]. The adsorbent was initially outgassed in a sample room at $350^{\circ} \mathrm{C}$ and $4.0 \times 10^{-4}$ Torr for $2 \mathrm{~h}$. Water was introduced to the sample room at a saturated water pressure and at room temperature. When water was adsorbed onto the samples in the sample room, the pressure was decreased by increasing the time under this constant volume. The amount of water adsorbed onto several samples was calculated from the pressure profile. This method revealed the behavior of water adsorption on the stronger adsorption sites, because the amount of water introduced into the sample room was limited. Only the slope of the adsorption initial behavior is discussed here.

\section{Results and Discussion}

\subsection{Framework Structures and Nitrogen Adsorption Isotherms of Several Samples}

Figure 1 shows the XRD patterns of Z02 (SAPO-34), alkali treated samples, and Z02- $\mathrm{NH}_{4} \mathrm{OH}$-C. Except for Z02-NaOH $(0.2 \mathrm{M})$, these patterns are identical to that of a CHA structure in the literature [11]. These results indicated alkali treatment by the relatively lower $\mathrm{NaOH}$ concentration $(<0.2 \mathrm{M})$ affected only the surface of SAPO-34, but the bulk of the structure was not changed by the treatment. This tendency agreed with the results of our previous studies [4] [5]. Previous papers showed that the alkali treatment of porous materials modified only the surface structure. SAPO-34 was also one of the porous materials. Omly the surface was modified by the alkali treatment. In the XRD pattern for $\mathrm{Z} 02-\mathrm{NaOH}$ 
$(0.2 \mathrm{M})$, however, some peak shifts were observed at around 17 and 26 degrees and missing peaks were observed at around 31 degrees. This could suggest either a structural change, or a collapse in the CHA structure.

SEM images for Z02 (SAPO-34), alkali treated, and $\mathrm{Z} 02-\mathrm{NH}_{4} \mathrm{OH}-\mathrm{C}$ samples, are shown in Figure 2. These occurred mainly in a cubic structure. The morphological changes in Z02 during alkali treatment using a $\mathrm{NaOH}(0.2 \mathrm{M})$ solution were quite dramatic. Some groves and voids that appeared on the surface of Z02 particles were caused by the alkali treatment with the $\mathrm{NaOH}(0.2 \mathrm{M})$ solution. Ogura et al. reported significant morphological changes in ZSM-5 zeolite during alkali treatment with $\mathrm{NaOH}(0.2 \mathrm{M})$ [12], and microporous SAPO-34
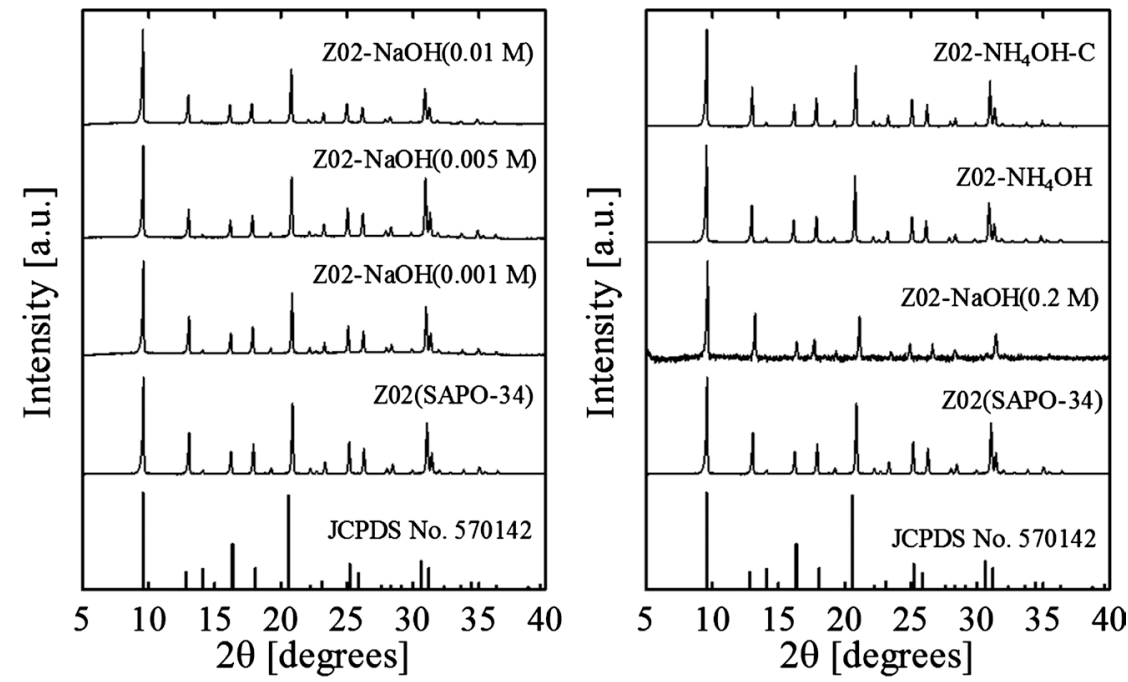

Figure 1. XRD patterns of several samples.
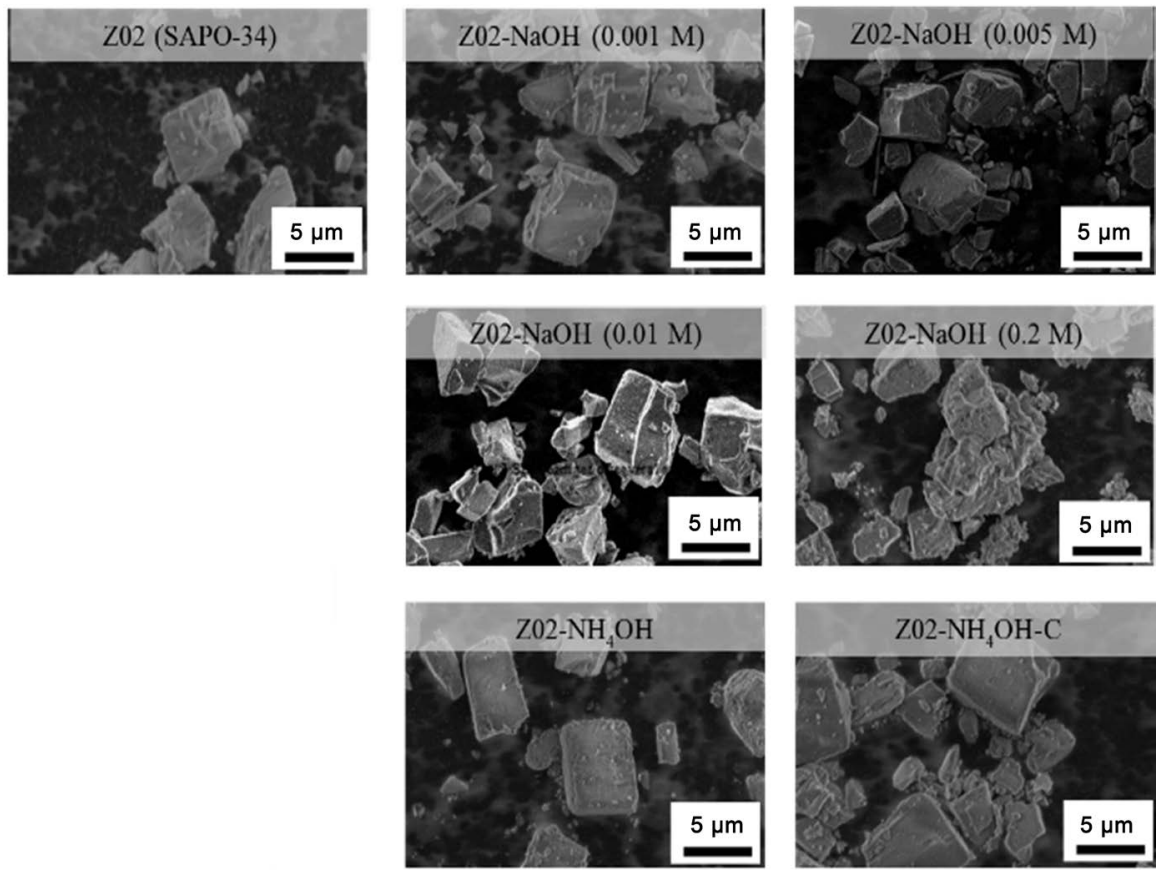

Figure 2. SEM iamges of several samples. 
showed a similar tendency. No obvious differences were observed, however, for either the other alkali treated samples or for $\mathrm{Z} 02-\mathrm{NH}_{4} \mathrm{OH}-\mathrm{C}$, which indicated that the obvious change in the surface morphology of Z02 was induced only by the relatively higher $\mathrm{NaOH}$ concentration $(0.2 \mathrm{M})$.

The $\mathrm{P} / \mathrm{Al}, \mathrm{Si} / \mathrm{Al}$, and $\mathrm{Mg} / \mathrm{Al}$ ratios, along with the $\mathrm{Na}$ content, are summarized in Table 1. With the exception of $\mathrm{ZO2}-\mathrm{NaOH}(0.2 \mathrm{M})$, the $\mathrm{P} / \mathrm{Al}$ and Si/Al ratios approximated that of $\mathrm{Z02}$ (SAPO-34). Although the $\mathrm{P} / \mathrm{Al}$ and $\mathrm{Si} / \mathrm{Al}$ ratios were maintained by treatment with a lower concentration of alkali solution, $\mathrm{P}$ and $\mathrm{Al}$ were removed from SAPO-34 under treatment with a $0.2 \mathrm{M}$ alkali solution. For $\mathrm{NaOH}$ treatment, however, the $\mathrm{Mg} / \mathrm{Al}$ ratio was maintained. These results indicated that neither the $\mathrm{Mg}^{2+}$ nor the $\mathrm{Mg}(\mathrm{OH})^{+}$ions were not changed by the $\mathrm{Na}^{+}$ in $\mathrm{NaOH}$ treatments [4]. The $\mathrm{Na}$ content was increased with an increase in the $\mathrm{NaOH}$ concentration. These results indicated that the $\mathrm{H}^{+}$was changed by $\mathrm{Na}^{+}$. These results were supported by IR measurement (Figure 3).

Figure 3 shows the IR spectra of pretreated samples. This spectra shows that the original SAPO-34 had several OH peaks, which were decreased by the alkali treatment $(0.001 \mathrm{M}$ to $0.01 \mathrm{M})$, and these disappeared following $0.2 \mathrm{M}$ of $\mathrm{NaOH}$ treatment. Conversely, with $\mathrm{NH}_{4} \mathrm{OH}$ treatment, the $\mathrm{Mg} / \mathrm{Al}$ ratio was decreased. This result indicated that some portion of $\mathrm{Mg}^{2+}$ was changed by the $\mathrm{NH}_{4}^{+}$in the $\mathrm{NH}_{4} \mathrm{OH}$ treatment, and that the $\mathrm{NH}_{4}^{+}$was changed to $\mathrm{H}^{+}$by calcination.

Table 1. $\mathrm{P} / \mathrm{Al}, \mathrm{Si} / \mathrm{Al}, \mathrm{Mg} / \mathrm{Al}$ ratios and $\mathrm{Na}$ content of several samples.

\begin{tabular}{ccccc}
\hline Sample & P/Al ratio [-] & Si/Al ratio [-] & $\mathrm{Mg} / \mathrm{Al}$ ratio [-] & $\mathrm{Na}[\mathrm{mol} \%]$ \\
\hline $\mathrm{Z} 02$ (SAPO-34) & 0.94 & 0.18 & 0.04 & - \\
$\mathrm{Z} 02-\mathrm{NaOH}(0.001 \mathrm{M})$ & 0.91 & 0.18 & 0.04 & 0.11 \\
$\mathrm{Z} 02-\mathrm{NaOH}(0.005 \mathrm{M})$ & 0.94 & 0.18 & 0.04 & 1.68 \\
$\mathrm{Z} 02-\mathrm{NaOH}(0.01 \mathrm{M})$ & 0.91 & 0.17 & 0.04 & 6.45 \\
$\mathrm{Z} 02-\mathrm{NaOH}(0.2 \mathrm{M})$ & 0.77 & 0.24 & 0.04 & - \\
$\mathrm{Z} 02-\mathrm{NH}_{4} \mathrm{OH}$ & 0.90 & 0.18 & 0.03 & - \\
$\mathrm{Z} 02-\mathrm{NH}_{4} \mathrm{OH}-\mathrm{C}$ & 0.93 & 0.18 & 0.03 & \\
\hline
\end{tabular}

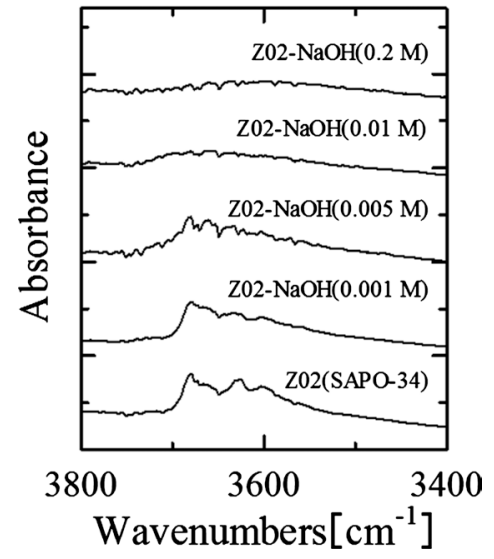

Figure 3. IR spectra of pretreated samples. 
Figure 4 shows the adsorption isotherms of nitrogen for several samples. Table 2 shows the Brunauer-Emmett-Teller (BET) specific surface area, the micropore volume, and the mesopore volume. Except for $\mathrm{Z} 02-\mathrm{NaOH}(0.005 \mathrm{M})$, both the BET surface area and the micropore volume of alkali-treated SAPO-34 were decreased. When SAPO-34 was alkali-treated with the $0.2 \mathrm{M} \mathrm{NaOH}$ solution, the CHA structure was changed in the XRD pattern (Figure 1), the SEM image showed a collapse of the surface structure, and the $\mathrm{N}_{2}$ adsorption isotherm showed that the pore structures had been damaged. The micropore volume was drastically decreased and the mesopore volume was increased. The pore structure of the ZSM- 5 was unchanged by alkali treatment with the $0.2 \mathrm{M} \mathrm{NaOH}$ solution. The concentration of $\mathrm{NaOH}(0.2 \mathrm{M})$, however, was too high for alkali treatment of SAPO-34. The results indicated that with alkali treatment the structure of SAPO-34 was weaker than that of ZSM-5. For NaOH, $0.005 \mathrm{M}$ solution proved to be the best concentration for the enhancement of nitrogen adsorption properties. The highest BET surface area was induced in the micro pores of SAPO-34 that were created by an alkali treatment using the optimum $\mathrm{NaOH}$ concentration of $0.005 \mathrm{M}$. The enhancement of water adsorption and desorption properties was also expected. On the other hand, the pore structure of SAPO-34 treated using $0.005 \mathrm{M}$ of $\mathrm{NH}_{4} \mathrm{OH}$ solution was not substantially changed, but both the BET surface area and the micropore volume were decreased by calcination.
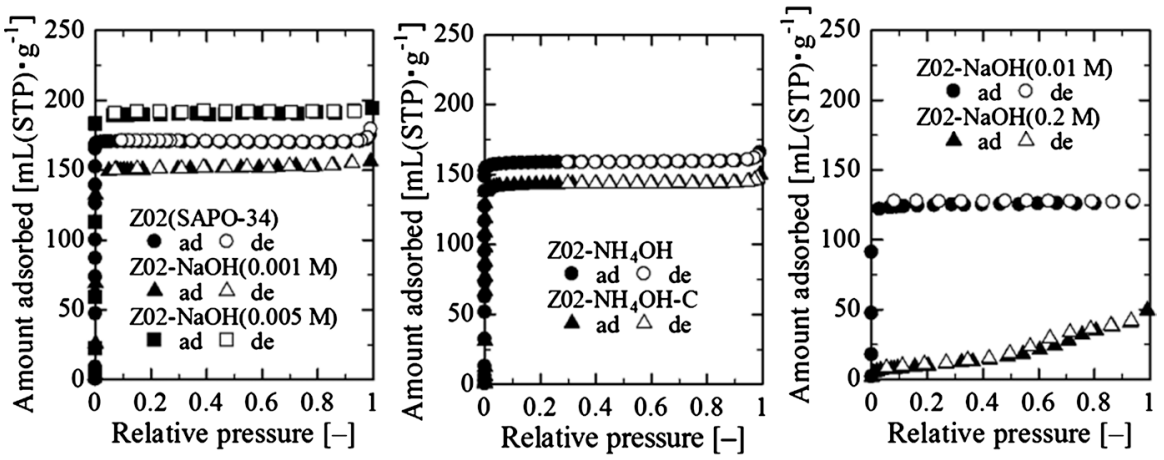

Figure 4. Nitrogen adsorption isothrems of several samples.

Table 2. Summary of physicochemical properties of several samples.

\begin{tabular}{cccc}
\hline Sample & $\begin{array}{c}\text { BET surface area } \\
{\left[\mathrm{m}^{2} / \mathrm{g}\right]}\end{array}$ & $\begin{array}{c}\text { Micropore volume } \\
{\left[\mathrm{cm}^{3} / \mathrm{g}\right]}\end{array}$ & $\begin{array}{c}\text { Mesopore volume } \\
{\left[\mathrm{cm}^{3} / \mathrm{g}\right]}\end{array}$ \\
\hline $\mathrm{Z} 02(\mathrm{SAPO}-34)$ & 716 & 0.28 & 0.02 \\
$\mathrm{Z} 02-\mathrm{NaOH}(0.001 \mathrm{M})$ & 621 & 0.25 & 0.01 \\
$\mathrm{Z} 02-\mathrm{NaOH}(0.005 \mathrm{M})$ & 770 & 0.32 & 0.01 \\
$\mathrm{Z} 02-\mathrm{NaOH}(0.01 \mathrm{M})$ & 517 & 0.20 & 0.01 \\
$\mathrm{Z} 02-\mathrm{NaOH}(0.2 \mathrm{M})$ & 36 & 0.03 & 0.08 \\
$\mathrm{Z} 02-\mathrm{NH}_{4} \mathrm{OH}$ & 672 & 0.27 & 0.02 \\
$\mathrm{Z} 02-\mathrm{NH}_{4} \mathrm{OH}-\mathrm{C}$ & 606 & 0.25 & 0.02 \\
\hline
\end{tabular}




\subsection{Water Adsorption and Desorption Behavior}

Figure 5 shows the normalized IR integrated intensity for several samples. The IR integrated intensity at $30^{\circ} \mathrm{C}$ and the desorption ratios (adsorption at $30^{\circ} \mathrm{C}$ and desorption at $80^{\circ} \mathrm{C}$ or $100^{\circ} \mathrm{C}$ ) are summarized in Table 3 . The temperature behavior was changed by the alkali treatment. After $\mathrm{NaOH}$ treatment, $\mathrm{Z02}-\mathrm{NaOH}$ $(0.005 \mathrm{M})$ had the highest IR integrated intensity of $30^{\circ} \mathrm{C}$. The best concentration for $\mathrm{NaOH}$ treatment was $0.005 \mathrm{M}$. These results were supported by the enhancement of $\mathrm{N}_{2}$ adsorption properties. Alkali treatment with higher concentrations of $\mathrm{NaOH}$ solution tended to damage the pore structure, but treatment with a lower concentration did not sufficiently affect the pore structure to increase micropore volume. Also, introducing the optimum amount of $\mathrm{Na}^{+}$exchanged by alkali treatment was also important. The desorption ratio of $\mathrm{Z} 02-\mathrm{NaOH}(0.01$ M) was smaller than that of $\mathrm{Z} 02-\mathrm{NaOH}(0.005 \mathrm{M})$. These results indicated that although a higher $\mathrm{NaOH}$ concentration can introduce a sufficient amount of $\mathrm{Na}^{+}$ into SAPO-34, the desorption ratios (adsorption at $30^{\circ} \mathrm{C}$ and desorption at $80^{\circ} \mathrm{C}$ or $100^{\circ} \mathrm{C}$ ) were decreased. Strong interaction between $\mathrm{Na}^{+}$and water prevented the release of water from SAPO-34. On the other hand, with $\mathrm{NH}_{4} \mathrm{OH}$ treatment, $\mathrm{Z} 02-\mathrm{NH}_{4} \mathrm{OH}$ had a higher IR integrated intensity at $30^{\circ} \mathrm{C}$ and $\mathrm{Z} 02-\mathrm{NH}_{4} \mathrm{OH}-\mathrm{C}$
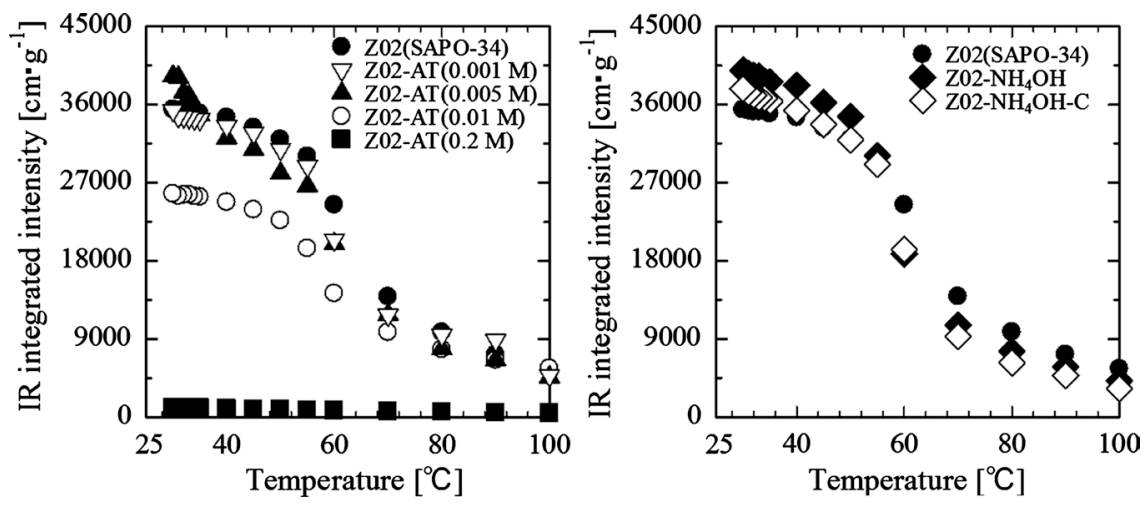

Figure 5. IR integrated intensity of adsorbed water at 10 Torr of several samples.

Table 3. IR integrated intensity at $30^{\circ} \mathrm{C}$ and desorption ratio (adsorption at $30^{\circ} \mathrm{C}$ and desorption at $80^{\circ} \mathrm{C}$ or $100^{\circ} \mathrm{C}$ ) of seveal samples.

\begin{tabular}{cccc}
\hline \multirow{2}{*}{ Sample } & $\begin{array}{c}\text { IR integrated intensity } \\
\text { at } 30^{\circ} \mathrm{C}\left[\mathrm{cm} \cdot \mathrm{g}^{-1}\right]\end{array}$ & $\begin{array}{c}\text { Desorption ratio (adsorption at } 30^{\circ} \mathrm{C} \\
\left.\text { and desorption at } 80^{\circ} \mathrm{Cor} 100^{\circ} \mathrm{C}\right)[\%]\end{array}$ \\
\cline { 3 - 4 } $\mathrm{Z} 02(\mathrm{SAPO}-34)$ & 35,400 & 72.3 & $100^{\circ} \mathrm{C}$ \\
$\mathrm{Z} 02-\mathrm{NaOH}(0.001 \mathrm{M})$ & 35,300 & 73.2 & 84.3 \\
$\mathrm{Z} 02-\mathrm{NaOH}(0.005 \mathrm{M})$ & 39,300 & 79.9 & 86.4 \\
$\mathrm{Z} 02-\mathrm{NaOH}(0.01 \mathrm{M})$ & 25,700 & 69.5 & 88.2 \\
$\mathrm{Z} 02-\mathrm{NaOH}(0.2 \mathrm{M})$ & 1100 & 43.2 & 78.0 \\
$\mathrm{Z} 02-\mathrm{NH}{ }_{4} \mathrm{OH}$ & 40,000 & 81.1 & 55.3 \\
$\mathrm{Z} 02-\mathrm{NH}_{4} \mathrm{OH}-\mathrm{C}$ & 37,800 & 83.5 & 89.6 \\
\hline
\end{tabular}


had a higher desorption ratio. As Figure 5 shows, $\mathrm{NH}_{4} \mathrm{OH}$ treatment decreased the amount of adsorbed water at higher temperatures $\left(80^{\circ} \mathrm{C}\right.$ and $\left.100^{\circ} \mathrm{C}\right)$. These results were supported by the change of $\mathrm{Mg}^{2+}$ to $\mathrm{NH}_{4}^{+}$and $\mathrm{H}^{+}$. Lower interaction between water and either $\mathrm{NH}_{4}^{+}$or $\mathrm{H}^{+}$decreased the amount of water adsorbed at higher temperatures.

Figure 6 showed the adsorption behavior of water. The slope of the adsorption initial behavior determined the adsorption initial rate [4], which is summarized in Table 4. Z02-NaOH $(0.005 \mathrm{M})$ had the highest rate of water adsorption. The increase in the micropore volume and introduction of an optimum amount of $\mathrm{Na}^{+}$sites induced the highest rate of water adsorption. These results indicated that treatment of SAPO-34 using an optimum concentration $(0.005 \mathrm{M})$ of $\mathrm{NaOH}$ enhanced both the amount of water adsorbed and the water adsorption rate. On the other hand, the treatment with $\mathrm{NH}_{4} \mathrm{OH}$ decreased the adsorption rate. This effect was explained by the low interaction between water and either $\mathrm{NH}_{4}^{+}$or $\mathrm{H}^{+}$.

\section{Conclusions}

The present study examined the effects that alkali treatment $\left(\mathrm{NaOH}\right.$ or $\left.\mathrm{NH}_{4} \mathrm{OH}\right)$ exerts on commercial silicoaluminophosphate molecular sieves (SAPO-34).

1) XRD patterns showed that, except for $0.2 \mathrm{M} \mathrm{NaOH}$ treatment, the other alkali treatments produced effects to SAPO-34 that were identical to that of CHA.
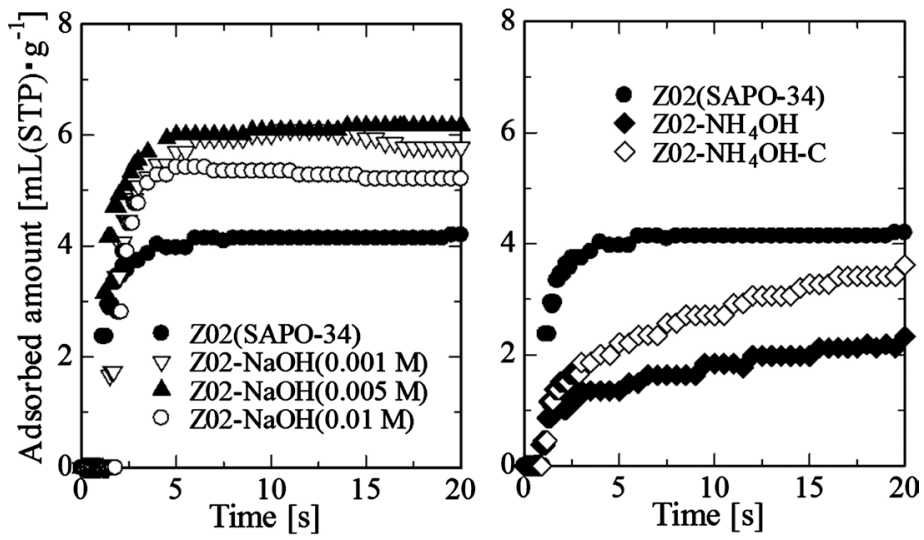

Figure 6. Adsorption behavior of water onto several samples $30^{\circ} \mathrm{C}$.

Table 4. Adsorption initial rate of several samples at $30^{\circ} \mathrm{C}$.

\begin{tabular}{cc}
\hline Sample & Adsorption initial rate $\left[\mathrm{mL}(\mathrm{STP}) \cdot \mathrm{g}^{-1} \cdot \mathrm{s}^{-1}\right]$ \\
\hline $\mathrm{Z} 02(\mathrm{SAPO}-34)$ & 2.7 \\
$\mathrm{Z} 02-\mathrm{NaOH}(0.001 \mathrm{M})$ & 3.5 \\
$\mathrm{Z} 02-\mathrm{NaOH}(0.005 \mathrm{M})$ & 3.9 \\
$\mathrm{Z} 02-\mathrm{NaOH}(0.01 \mathrm{M})$ & 3.5 \\
$\mathrm{Z} 02-\mathrm{NH}_{4} \mathrm{OH}$ & 1.2 \\
$\mathrm{Z} 02-\mathrm{NH}_{4} \mathrm{OH}-\mathrm{C}$ & 1.4 \\
\hline
\end{tabular}


2) SEM images of all treated materials showed mainly in a cubic structure. Obvious changes to the surface morphology of SAPO-34 were induced only by a relatively higher $\mathrm{NaOH}$ concentration $(0.2 \mathrm{M})$.

3) SAPO-34 samples treated with $0.005 \mathrm{M} \mathrm{NaOH}$ showed the highest amount of adsorbed water at $30^{\circ} \mathrm{C}$ as well as the highest adsorption capacities (adsorption at $30^{\circ} \mathrm{C}$ and desorption at 80 or $100^{\circ} \mathrm{C}$ ).

4) For $\mathrm{NH}_{4} \mathrm{OH}$ treated samples, the amount of adsorbed water at $30^{\circ} \mathrm{C}$ and the effective adsorption capacities (adsorption at $30^{\circ} \mathrm{C}$ and desorption at $80^{\circ} \mathrm{C}$ or $100^{\circ} \mathrm{C}$ ) were higher than for $\mathrm{NaOH}$-treated samples, but the adsorption initial rate was less than half that of the $\mathrm{NaOH}$ treated samples due to the low interaction between water and either $\mathrm{NH}_{4}^{+}$or $\mathrm{H}^{+}$.

5) When SAPO-34 was treated with $0.005 \mathrm{M} \mathrm{NaOH}$, the initial rate pf water adsorption at $30^{\circ} \mathrm{C}$ was about 1.4 times that of the original rate, which represented a higher amount of adsorbed water and a higher effective adsorption capacity than that of other alkali treatments of SAPO- 34 by $\mathrm{NaOH}$ solutions. These results indicated that treatment of commercial SAPO-34 with $0.005 \mathrm{M} \mathrm{NaOH}$ produced the most advantageous conditions for water adsorbancy.

\section{Conflicts of Interest}

The authors declare no conflicts of interest regarding the publication of this paper.

\section{References}

[1] Lok, B. M., Messina, C.A., Patton, R.L., Gajek, R.T., Cannan, T. R. and Flanigen, E.M. (1984) Crystalline Silicoaluminophosphates. US Patent 4440871.

[2] Lok, B.M., Messina, C.A., Patton, R.L., Gaiek, R.T., Cannan, T.R. and Flanigen, E.M. (1984) Silicoaluminophosphate Molecular Sieves: Another New Class of Microporous Crystalline Inorganic Solids. Journal of the American Chemical Society, 106, 6092-6093. https://doi.org/10.1021/ja00332a063

[3] Kubokawa, S. (2011) Development of New Product Using AQSOA. Adsorption News, 25, 6-11.

[4] Katoh, M., Kimura, M., Sugino, M., Horikawa, T., Nakagawa, K. and Sugiyama, S. (2015) Modification of Commercial NaY Zeolite to Give High Water Diffusivity and Adsorb a Large Amount of Water. Journal of Colloid and Interface Science, 455, 220-225. https://doi.org/10.1016/j.jcis.2015.05.050

[5] Katoh, M., Satoh, A., Horikawa, T., Nakagawa, K. and Sugiyama, S. (2016) The Effects of Created Mesopores in ZSM-5 Zeolites by an Alkali Treatment on Water Adsorption. Journal of Chemical Engineering of Japan, 49, 120-125.

[6] Katoh, M., Koide, R., Yamada, K., Yoshida, T. and Horikawa, T. (2012) IR Spectroscopic Analysis of Thermal Behavior of Adsorbed Water on Y-type Zeolite. In ternational Journal of Modern Physics: Conference Series, 6, 437-442. https://doi.org/10.1142/S2010194512003571

[7] Katoh, M., Satoh, A., Kimura, M. and Sugiyama, S. (2019) Enhancement of Water Adsorption-desorption Performance of Aluminophosphate Molecular Sieves (AlPO-5) Substituted with Several Metals. Journal of Chemical Engineering of Japan, 52, 210-214. 
[8] Yamazaki, T., Watanuki, I., Ozawa, S. and Ogino, Y. (1987) An IR Study on Methane Adsorbed on ZSM-5 Type Zeolites. Nippon Kagaku Kaishi, 1987, 1535-1540.

[9] Yamazaki, T., Watanuki, I., Ozawa, S. and Ogino, Y. (1988) Infrared Spectra of Methane Adsorbed by Ion-Exchanged ZSM-5 Zeolites. Langmuir, 4, 433-438. https://doi.org/10.1021/la00080a031

[10] Katoh, M., Yoshikawa, T., Tomonari, T., Katayama, K. and Tomida, T. (2000) Adsorption Characterization of Ion-Exchanged ZSM-5 Zeolites for $\mathrm{CO}_{2} / \mathrm{N}_{2}$ Mixtures. Journal of Colloid and Interface Science, 226, 145-150. https://doi.org/10.1006/jcis.2000.6795

[11] Digital Data Management Corp. (1997) PCPDFWIN, Version 1.30, JCPDS-ICDD, File 570142

[12] Ogura, M., Shinomiya, S. Tateno, J., Nara, Y., Nomura, M., Kikuchi, E. and Matsukata, M. (2000) Formation of Uniform Mesopores in ZSM-5 Zeolite through Treatment in Alkaline Solution. Chemistry Letters, 29, 882-883.

https://doi.org/10.1246/cl.2000.882 